\title{
Penyelesaian Peselisihan Perjanjian Kerja Sama antara Asosiasi Bongkar Muat dengan Koperasi Tenaga Bongkar Muat Upaya Karya
}

\section{Settlement of Disputes between the Cooperation Agreement between the Loading Unloading Association and the Workload Unloading Cooperative}

\author{
Gomgom T.P. Siregar \\ Fakultas Hukum, Universitas Darma Agung Medan, Indonesia \\ Diterima: Desember 2019; Disetujui: Desember 2019; Dipublish: Desember 2019 \\ *Coresponding Email: gomgom@gmail.com
}

\begin{abstract}
Abstrak
Tujuan dari penulisan ini adalah untuk mendeskripsikan faktor penyebab terjadinya perselesihan dalam sebuah kerjasama, prosedur penyelesaian perselisihan kerja sama dan penyelesaian melalui prosedur non litigasi. Jenis Penelitian yang digunakan dalam penelitian ini adalah penelitian hukum normatif (normatif research) dengan fokus permasalahan terkait bagaiamana penyelesaian perselisihan kerja sama antara asosiasi bongkar muat dengan koperasi tenaga bongkar muat upaya karya. Berdasarkan hasil penelitian diketahui bahwa penyelesaian perselisihan kerja sama antara asosiasi bongkar muat dengan koperasi tenaga bongkar muat upaya karya dapat dilakukan melalui prosedur Litigasi maupun prosedur Non Litigasi.
\end{abstract}

Kata Kunci: Perjanjian Kerja Sama, Asosiasi, Bongkar Muat

\begin{abstract}
The purpose of this paper is to describe the factors causing disputes in a collaboration, procedures for the resolution of cooperation disputes and settlement through non-litigation procedures. This type of research used in this research is normative legal research with the focus of problems related to how the dispute resolution of cooperation between loading and unloading associations with the labor force loading and unloading effort cooperatives. Based on the results of the study, it is known that the settlement of cooperation disputes between the stevedoring association with the stevedoring labor cooperative can be carried out through litigation and non-litigation procedures.
\end{abstract}

Keywords: Cooperation Agreement, Association, Loading and Unloading

How to Cite: Siregar, G.T.P. (2019). Penyelesaian Peselisihan Perjanjian Kerja Sama antara Asosiasi Bongkar Muat dengan Koperasi Tenaga Bongkar Muat Upaya Karya. Journal of Education, Humaniora and Social Sciences (JEHSS). 2 (2): 370-381. 


\section{PENDAHULUAN}

Itikad baik seharusnya dimiliki oleh setiap individu sebagai bagian dari makhluk sosial yang tidak dapat saling melepaskan diri dari ketergantungan sosial terhadap individu lain untuk saling bekerjasama, saling menghormati dan menciptakan suasana tenteram bersama-sama. Melepaskan diri dari keharusan adanya itikad baik dalam setiap hubungan dengan masyarakat adalah pengingkaran dari kebutuhannya sendiri; kebutuhan akan hidup bersama, saling menghormati dan saling memenuhi kebutuhan pribadi dan sosial. Suatu perjanjian yang tidak dijalankan dengan itikad baik tentu akan menimbulkan wanperstasi. Mengingat akibat-akibat yang timbul dari wanprestasi itu begitu penting, maka harus ditetapkan terlebih dahulu apakah pihak yang berjanji benarbenar melakukan wanprestasi. Dan apabila hal tersebut disangkal olehnya, maka harus dibuktikan di muka pengadilan.

Pada prakteknya memang tidak mudah menyatakan bahwa seseorang itu lalai atau alpa atau melakukan wanprestasi. Problematika tentang iktiad baik dalam pelaksanaan sebuah perjanjian juga kerap terjadi dalam berbagai bentuk perjanjian termasuk perjanjian kerja sama. Salah satunya dapat dilihat pada Perjanjian Kerja Sama Antara Asosiasi Bongkar Muat Dengan Koperasi Tenaga Bongkar Muat Upaya Karya. Legal standing perjanjian kerja sama dimaksud merujuk pada Instruksi Bersama Menteri Perhubungan dan Menteri Tenaga Kerja Nomor: IM.2/HK.601/PHB-89 dan Nomor: INS.03/MEN/89 tentang Pembentukan Koperasi Pelabuhan Sebagai Pengganti Yayasan Usaha Karya, dan ketentuan Peraturan Menteri Perhubungan Nomor: PM.60 Tahun 2014 dan PM. 93 Tahun 2015 tentang Penyelenggaraan Dan Pengusahaan Bongkar Muat Barang. Mengingat pentingnya permasalahan tentang Problematika tentang iktiad baik dalam pelaksanaan sebuah perjanjian, maka penulis ingin mengangkat penelitian tentang "Penyelesaian Peselisihan Perjanjian Kerja Sama Antara Asosiasi Bongkar Muat Dengan Koperasi Tenaga Bongkar Muat Upaya Karya”

\section{METODE PENELITIAN}

Penelitian hukum pada dasarnya merupakan suatu kegiatan ilmiah yang didasarkan pada metode, sistematika dan pemikiran tertentu yang bertujuan untuk mempelajari satu atau beberapa gejala hukum tertentu dengan jalan menganalisanya, kecuali itu maka juga diadakan pemeriksaan yang mendalam terhadap fakta hukum tersebut untuk 
kemudian yang ditimbulkan di dalam gejala yang bersangkutan (Soekanto. 1981). Spesifikasi penelitian yang dilakukan dalam penelitian ini adalah penelitian hukum normatif. Penelitian hukum normatif dilakukan guna melihat hukum dari suatu sistem normatif yang bersifat otonom, terlepas dari kehidupan masyarakat (Salindheo, 1988), dengan maksud untuk menggambarkan keadaan yang ada dengan mempergunakan metode penelitian ilmiah. Jenis penelitian dalam penelitian ini adalah penelitian hukum normative (Soekanto. 1981). Sifat penelitian ini adalah deskriptif analisis yaitu penelitian yang menggambarkan objek, menerangkan dan menjelaskan sebuah peristiwa dengan maksud untuk mengetahui keadaan objek yang diteliti. Sifat penelitian deskriptif dimaksudkan untuk memberikan data yang seteliti mungkin tentang manusia, keadaan atau gejala-gejala lainnya (Soekanto. 1981).

Menurut Sumadi Suryabrata, penelitian deskriptif adalah penelitian yang bernaksud untuk membuat pencandraan (deskripsi) mengenai situasi-situasi atau kejadian-kejadian. Penelitian deskriptif adalah akumulasi data dasar dalam cara cara deskripsi semata-mata tidak perlu mencari atau menerangkan saling hubungan, mentest hipotesis, membuat ramalan, atau mendapatkan makna dari implikasi (Suryabrata. 2006). Penelitian hukum yuridis normatif membutuhkan sumber data yang berasal dari data sekunder berupa bahan hukum primer, bahan hukum sekunder dan bahan hukum tersier. Bahan hukum primer, yakni Undang-Undang, Peraturan Pemerintah, dan Kitab Hukum Perdata; Bahan hukum sekunder, yakni semua dokumen yang merupakan hasil penelitian para ahli, hasil karya ilmiah, buku-buku ilmiah, informasi atau merupakan hasil kajian dari berbagai media seperti koran, dan artikel yang dimuat di website internet yang berkaitan dengan perjanjian khususnya perjanjian Standar; Bahan hukum tertier, yakni bahan yang bisa memberikan petunjuk dan penjelasan terhadap bahan hukum primer seperti ensiklopedi, majalah, artikel-artikel, surat kabar dan jurnal-jurnal hokum.

Pelaksanaan penelitian hukum yuridis normatif pada penulisan ini secara garis besar di tunjukan kepada Penelitian terhadap asas-asas hukum, misalnya terhadap hukum positif atau penelitian terhadap kaidah hukum yang hidup dalam masyarakat; 2) Penelitian terhadap sistematika hukum, yakni dengan menelaah pengertian dasar dan sistem hukum dalam perundang-undangan 


\section{HASIL DAN PEMBAHASAN}

\section{Faktor Penyebab Terjadinya Perselesihan dalam Sebuah Kerjasama}

Ada berbagai faktor penyebab kemungkinan terjadinya suatu perjanjian yang sudah dibuat tetapi tidak dapat dilaksanakan. Faktor-faktor penyebab tersebut dapat diuraikan sebagai berikut: a) Kelalaian atau wanprestasi, Seorang debitur atau pihak yang harus memenuhi prestasinya dikatakan lalai apabila: Pertama tidak memenuhi kewajiban, Kedua terlambat memenuhinya, Ketiga memenuhinya tetapi tidak seperti yang telah diperjanjikan atau tidak sempurna. b) Keadaan Memaksa atau Overmacht, overmacht yaitu suatu kedaan diluar kekuasaannya si berutang. Keadaan yang telah timbul itu juga harus berupa suatu keadaan yang tidak dapat diketahui pada waktu perjanjian dibuat, setidaknya tidak dapat dipikul risikonya oleh si berutang.

Ada dua macam overmacht, yaitu: Pertama bersifat mutlak, yakni tidak mungkin lagi melaksanakan perjanjian; Kedua, bersifat relatif, yakni suatukedaan dimana perjanjian masih dapat dilaksanakan, tetapi dengan pengorbanan yang sangat besar dari hak si berutang. Pada umumnya perjanjian tidak terikat kepada suatu bentuk tertentu, dapat dibuat secara lisan dan andaikata dibuat secara tertulis maka ini bersifat sebagai alat bukti apabila terjadi perselisihan (Badrulzaman, Sjahdeini, dkk. 2001). Perjanjian dalam Kitab Undang-Undang Hukum Perdata (KUH Perdata) tidak diatur secara baku dan kaku, bahkan bersifat terbuka. Hal ini berarti bahwa dalam suatu perjanjian, para pihak dapat menyesuaikan apa yang tersirat dan dipikirkan dalam hati masing-masing yang kemudian dimusyawarahkan untuk diwujudkan secara nyata dengan cara merangkumnya ke dalam klausula-klausula isi perjanjian oleh mereka yang mengadakan perjanjian.

Untuk mengukur potensi perselisihan dalam pelaksanaan itikad baik perjanjian kerjasama Antara Asosiasi Bongkar Muat Dengan Koperasi Tenaga Bongkar Muat Upaya Karya, maka masing-masing pihak yang melakukan kerja sama harus pula mengetahui hak dan kewajibannya. Selama melakukan usahanya, Perusahaan Bongkar Muat memiliki kewajiban yang harus dipenuhi. Kewajibannya adalah sebagai berikut (Kamaluddin, 1983) Melaksanakan ketentuan-ketentuan yang ditetapkan dalam izin usaha dalam keputusan ini dan kebijaksanaan umum pemerintah di bidang penyelenggaraan kegiatan bongkar muat dari dan ke kapal; Memenuhi batas minimal kecepatan bongkar muat barang yang telah ditetapkan pada setiap pelabuhan; c) Mengenakan/memberlakukan 
tarif yang berlaku sesuai peraturan; Meningkatkan keterampilan kerja; Bertanggung jawab terhadap barang selama berada di bawah pengawasannya; Bertanggung jawab kepada kerusakan alat bongkar muat (gear) kapal yang disebabkan oleh kesalahan, kelalaian orang-orang yang bekerja di bawah pengawasannya; Menyampaikan laporan kegiatan usahanya secara berkala kepada: Administrator Pelabuhan setempat berupa laporan harian, bulanan dan tahuna dan Direktur Jenderal Pelabuhan Laut, dalam hal ini adalah Kepala Direktorat Lalu Lintas Angkatan Laut dan Kakanwilhubla setempat berupa laporan bulanan dan tahunan; h) Menaati segala peraturan perundangan yang berlaku.

Lebih lanjut, dalam menjalankan tugas dan tanggung jawab perusahaan bongkar muat dalam melakukan pelayanan maka perusahaan bongkar muat harus bekerja sama dengan berbagai pihak seperti PT Pelabuhan Indonesia, perusahaan pelayaran, EMKL, pemilik barang, penyedia tenaga buruh dan sebagainya. Masing-masing pihak memiliki tugas dan tanggung jawab. Sedangkan Perusahaan Bongkar Muat memiliki tanggung jawab atas Kelancaran kegiatan bongkar muat; Keselamatan penerimaan dan penyerahan barang; Kebenaran laporan yang disampaikan; Mengatur penggunaan Tenaga Kerja Bongkar Muat dan peralatan sesuai kebutuhan.

Di dalam KUH Perdata buku III diatur mengenai pelbagai persetujuan tertentu, seperti jual beli, sewa menyewa, tukar menukar barang, pemberian kuasa, perjanjian perburuhan, pemborongan kerja dan lain-lain. Menurut HMN. Purwosutjipto bahwa perjanjian pengangkutan tidak termasuk ke dalam salah satu perjanjian tertentu yang di atur dalam KUH Perdata. Demikian juga pendapat Prof. Wirjonoprojhodikoro (Kamaluddin, 1983). Persamaan antara perjanjian pengangkutan dan pemberian kuasa hanya terdapat dalam hal unsur menyuruh orang lain mengerjakan sesuatu bagi kepentingan pihak yang menyuruh. Tetapi perbedaan yang sangat mendasar bahwa dalam pemberian kuasa, ada hubungan yang hakiki dan erat antara yang memberi kuasa dan yang diberi kuasa. Biasanya pemberian itu diikuti dengan suatu perwakilan, yaitu si pemberi kuasa diwakili oleh yang diberi kuasa dalam suatu perbuatan tertentu sehingga dengan perbuatan tersebut timbul hubungan hukum antara si pemberi kuasa dan orang ketiga.

Unsur perwakilan dapat dikatakan asing dalam perjanjian pengangkutan, oleh karena dalam hal orang diwakili oleh orang lain, perbuatan yang disuruh untuk dilakukan, dapat dilakukan oleh si pemberi kuasa sendiri dan penyuruh orang lain pada 
hakikatnya hanya dilakukan dalam hal si pemberi kuasa berhalangan atau berkeberatan untuk melakukan perbuatan itu sendiri. Dalam perjanjian kerjasama bongkar muat, pihak yang menyuruh membngkar atau pihak yang memindahkan barang pada hakikatnya tidak dapat melakukan sendiri pembongkaran itu dan harus menyuruh orang lain yang dapat dan biasanya juga melakukan pembongkaran barang. Jadi dalam pemberian kuasa perlu dibuat suatu pasal-pasal yang jelas mengenai hubungan antara pihak pemberi kuasa dan pihak penerima kuasa. Hal tersebut tidak diperlukan dalam perjanjian kerjasama bongkar muat. Demikian juga tentang perjanjian pemborongan pekerjaan.

Pemborongan kerja mengarahkan perhatian pada hasil dari suatu rangkaian perbuatan-perbuatan yang dalam keseluruhannya menjadi tujuan dari persetujuan itu, sedangkan dalam perjanjian bongkar muat hanya mengenai pemindahan barang atau orang dari suatu tempat ke tempat lain. Hal ini sesuai dengan bunyi pasal 1617 KUH Perdata bahwa mengenai pemborongan kerja ketentuan hal-hal mengenai pengangkutan barang dan nahkoda kapal diatur dalam KUH Dagang. Jadi jelas bahwa pemborongan kerja tidak berlaku bagi perjanjian bongkar muat (Wirjonoprojhodikoro. 1982), sehingga dengan demikian dapat dikatakan bahwa perjanjian bongkar muat tidak termasuk kepada perjanjian-perjanjian tertentu seperti yang diatur dalam KUH Perdata, akan tetapi merupakan jenis perjanjian khusus yang diatur dalam KUH Dagang.

Nilai dan daya guna suatu barang tidak hanya tergantung dari barang itu sendiri, tetapi juga tergantung pada tempat dimana barang itu berada, misalnya di Medan dengan di Berastagi, dimana hampir di tiap-tiap rumah petani sayuran bertumpuk sayuran kol dan sejenisnya sampai menggunung. Disana harga kol sangat murah, tetapi setelah diangkut ke Medan, maka harga kol tersebut akan menjadi dua atau tigakali lipat. Misalnya lagi, bahwa di Maluku rempah-rempah nilainya tidak begitu tinggi jika dibandingkan dengan di Eropa atau di America sana. Dalam menaikkan dan meningkatkan nilai suatu barang terdapat fungsi dan peran pengangkutan. Inilah jasa pengangkutan.

Para pedagang mempergunakan jasa angkutan ini sebagai salah satu cara untuk mendapatkan keuntungan. Dari contoh di atas jelas bahwa pengangkutan memegang peranan yang sangat penting dalam lalu-lintas perdagangan dalam masyarakat. Dari sejak dahulu pengangkutan telah ada walaupun masih bersifat sederhana, sudah ada 
hubungan dagang antara benua Tiongkok dan Indonesia dan sudah barang tentu hubungan dagang ini dilaksanakan melalui laut. Di negeri Belanda pada waktu mulai diadakan kodefikasi dari hukum-hukum yang berlaku, juga perihal pengangkutan di laut diadakan peraturan, yaitu yang termuat dalam buku II Wetboek van Koophandel yang mulai berlaku pada tanggal 1 Oktober 1838. Untuk melakukan konkordansi atau penyesuaian, maka di Indonesia peraturan semacam itu diadakan pula, juga bersamasama dengan KUH Dagang, yang bersama-sama dengan peraturan lain mulai berlaku pada tanggal 1 Mei 1848 (Wirjonoprojhodikoro. 1982).

Pada saat sekarang peraturan pengangkutan laut itu masih bersumber pada buku II KUH Dagang produk pemerintah Hindia Belanda, walaupun beberapa kententuan tentang pengangkutan laut itu sudah diadakan pengaturannya oleh pemerintah. Dengan memperhatikan perkembangan teknologi yang sudah sedemikian majunya maka KUH Dagang pada dewasa ini kurang sesuai lagi dengan kebutuhan yang berkembang bagi keperluan pengangkutan di laut. Terlebih-lebih semakin meningkatnya hubungan antar negara dimana Indonesia terlibat didalamnya maka dalam melaksanakan pelayaran keluar negeri harus disesuaikan dengan peraturan yang berlaku bagi Pelayaran Internasional, yang dalam hal-hal tertentu pada prinsipnya berbeda dengan ketentuanketentuan dalam KUH Dagang.

Berdasarkan perkembangan yang menyangkut bidang pengangkutan laut memang telah digunakan konvensi-konvensi Internasional yang berhubungan dengan pelaksanaan Pelayaran Internasional. Tujuan utama dari konvensi-konvensi internasional tersebut adalah agar tercipta suatu keseragaman pada negar-negara di dunia ini yang menyangkut hukum pengangkutan di laut. Telah disinggung di atas bahwa pada dasarnya fungsi pengangkutan telah memindahkan barang atau orang dari suatu tempat ke tempat yang lain dengan maksud untuk meningkatkan daya guna dan nilai dari barang tersebut. Jelas bahwa meningkatkan daya guna dan nilai barang atau orang adalah merupakan tujuan dari pengangkutan. Artinya bahwa bila daya guna dan nilai suatu barang atau orang di tempat yang baru tidak naik maka pengangkutan tidak perlu diadakan, sebab merupakan suatu perbuatan yang merugikan bagi si pedagang (Marpaung, Arifin \& Hidayani, 2016Dharmaputra \& Januari, 2010; Simorangkir \& Januari, 2010). 
Dari hal di atas terlihat bahwa pengangkutan mempunyai fungsi yang sangat vital. Kevitalannya bukan hanya dari segi fisik saja, yakni alat yang harus membawa barangbarang yang diperdagangkan dari produsen ke konsumen misalnya, tetapi juga sebagai alat penentu dari harga barangbarang. Oleh karena itu bagi kepentingan perdagangan, setiap pedagang selalu akan berusaha mendapatkan frekuensi angkutan yang kontiniu dan tinggi dengan biaya angkutan yang rendah. Untuk kesemua hal diatas diperlukan suatu perangkat peraturan lalu lintas baik di darat udara maupun di laut, sehingga tercipta suatu kepastian hukum baik di pihak produsen maupun konsumen, juga di pihak pedagang sebagai perantara (Syaparudin, Ferri \& Henry, 2010; Sumardi \& Mubarak, 2018; Nasution, 2018).

\section{Prosedur Penyelesaian Perselisihan Kerja Sama melalui Prosedur Litigasidan Nonlitigasi}

Penyelesaian perselisihan yang disebabkan oleh adanya wanprestasi atas perjanjian kerja sama antara asosiasi bongkar muat dengan koperasi tenaga bongkar Muat upaya karya dapat dilakukan dengan prosedur Litigasi dan Non Litagasi. Prosedur litigasi kerap dikenal dengan langkah menggugat ke pengadilan. Istilah gugatan oleh Sudikno Mertokusumo dinamakan tuntutan perdata tentang hak yang mengandung sengketa dengan pihak lain, begitu juga Subekti mempergunakan sebutan gugatan yang dituangkan dalam surat gugatan, dengan demikian setiap perkara perdata diajukan ke Pengadilan Negeri dalam bentuk surat gugatan (Himpunan Peraturan PerundangUndangan RI.).

Gugatan perdata adalah merupakan gugatan contentiosa yang mengandung sengketa diantara pihak yang berperkara yang pemeriksaan penyelesaiannya diberikan dan diajukan kepada pengadilan dengan posisi para pihak: a) Yang mengajukan penyelesaian sengketa disebut dan bertindak sebagai penggugat; b) Sedangkan yang ditarik sebagai pihak lawan dalam penyelesaian disebut dan berkedudukan sebagai tergugat; Dengan demikian ciri yang melekat pada gugatan perdata: Permasalahan hukum yang diajukan ke pengadilan mengandung sengketa (disputes, differences); Sengketa terjadi diantara para pihak, sedikitnya dua pihak; Berarti gugatan perdata bersifat partai (party), dengan komposisi pihak yang satu bertindak dan berkedudukan sebagai penggugat dan pihak yang lain berkedudukan sebagai tergugat (Harahap, 2009). 
Lebih jauh, prinsip penting yang harus dipegang oleh negara hukum adalah terjaminnya penyelenggaraan kekuasaan kehakiman yang merdeka. Arti merdeka disini adalah bebas dari pengaruh kekuasaan lain saat menyelenggarakan peradilan guna menegakkan keadilan, kebenaran, dan kepastian hukum. Agar ini terwujud perlu pengaturan susunan, kekuasaan, serta lingkungan peradilan umum. Upaya penyelesaian melalui jalur peradilan (litigasi) melalui Peradilan Umum dan Peradilan Tata Usaha Negara. Peradilan Umum yang dasar pembentukannya Undang-Undang Republik Indonesia Nomor 51 Tahun 2009 tentang Perubahan kedua atas Undang-Undang Nomor 2 Tahun 1986 tentang Peradilan Umum merupakan salah satu pelaksana kekuasaan kehakiman bagi rakyat pencari keadilan pada umumnya (Pasal 2 Undang-Undang Nomor 2 Tahun 1986).

Kekuasaan kehakiman di lingkungan peradilan umum dijalankan oleh: a) Pengadilan Negeri yang merupakan Pengadilan tingkat pertama; b) Pengadilan Tinggi yang merupakan pengadilan tingkat banding; c) Pengadilan kehakiman di lingkungan peradilan umum berpuncak pada Mahkamah Agung RI sebagai pengadilan negara tertinggi (Pasal 3 UU Nomor 2 Tahun 1986). Dalam menyelesaikan sengketa di pengadilan umum digunakan hukum acara perdata yang bertujuan untuk memelihara dan mempertahankan hukum perdata materiil. Ikhwal hukum acara perdata, Wirjono Projodikoro menyatakan hukum acara perdata adalah rangkaian peraturan-peraturan yang memuat cara bagaimana orang harus bertindak dimuka pengadlan dan bagaimana pengadilan itu harus bertindak satu sama lain untuk melaksanakan peraturan-peraturan hukum perdata I (Wantjik. 1997). Dalam peradilan tugas hakim ialah mempertahankan tata hukum perdata (burgerlijk rechtsorde), menetapkan apa yang ditentukan oleh hukum dalam suatu perkara.

\section{Penyelesaian Melalui Prosedur Non Litigasi}

Proses penyelesaian perselisihan atau sengketa kerjasama bongkar muat melalui prosedur non litigasi adalah penyelesaian perselisihan di luar pengadilan. Langkah ini kerap dinamai dengan sebutan Alternatif Penyelesaian Sengketa (APS) atau dalam bahasa Inggris disebut Alternative Disputes Resolution (ADR). Ada juga yang menyebutkan sebagai mekanisme Penyelesaian Sengketa Secara Koorperatif (MPSSK) (Abdurrasyid. 2002). Proses penyelesaian perselisihan di luar pengadilan pada 
umumnya dapat dilakukan melalui berbagai cara berikut: a) Negosiasi, Merupakan salah satu pola atau langkah utama dalam Alternative Disputes Resolution (ADR). Negosiasi melibatkan dua atau lebih pihak yang berkepentingan. Tujuannya agar tercapai suatu kesepakatan. Dengan begitu mereka dapat bekerja sama lagi. Negosiasi sering terjadi di dunia usaha sebab esensinya adalah komunikasi dan tawar-menawar; b) Mediasi (Mediation), Mediasi atau dalam bahasa Inggris disebut mediation, menurut M. Echols \& Hasan Shadily adalah penyelesaian sengketa dengan menengahi dengan melibatkan pihak mediator sebagai orang yang menjadi penengah (Emirzon. 2000). Sedangkan menurut Folberg \& Taylor mediasi adalah suatu proses dimana para pihak dengan bantuan seseorang atau beberapa orang, secara sistematis menyelesaikan permasalahan yang disengketakan. Tujuannya mencari alternatif dan mencapai penyelesaian yang dapat mengakomodasi kebutuhan mereka (Emirzon. 2000).

Menurut Abdurrasyid (2002) mediasi adalah suatu proses penyelesaian sengketa di mana para pihak yang berselisih memanfaatkan bantuan pihak ketiga yang independen sebagai mediator (penengah), namun penengah tidak diberi wewenang untuk mengambil keputusan yang mengikat. Dengan menggunakan berbagai prosedur, teknik, dan keterampilan perundingan, negosiator membantu para pihak menyelesaikan perselisihan mereka. Mediator juga merupakan seorang fasilitator yang jika diperlukan dalam beberapa bentuk mediasi memberikan evaluasi yang tidak mengikat mengenai nilai perselisihan. Tetapi dia tidak diberi wewenang membuat keputusan yang mengikat. Keberhasilan proses mediasi sangat tergantung pada keinginan para pihak untuk berbicara satu sama lain dan menetapkan sasaran pembahasan untuk menemukan solusi yang dapat diterima masing-masing pihak.

Peran mediator sendiri dalam membantu para pihak adalah secara sistematis berusaha mengisolasi isu-isu konflik agar tidak melukai para pihak. Jika proses mediasi tidak berhasil, para pihak masih dapat didorong menyelesaikan konfliknya dengan cara lain, misalnya arbitrasi. Mengembangkan dan mencari berbagai kemungkinan untuk menyelesaikan konflik merupakan tugas mediator. Juga mencari kesepakatan yang dapat mengakomodasi kepentingan masing-masing pihak bersengketa. Konsiliasi (conciliation) dapat diartikan sebagai usaha mempertemukan keinginan pihak yang berselisih agar mereka sepakat menyelesaikan masalah. 
Konsiliasi merupakan proses penyelesaian sengketa dengan menyerahkannya ke suatu komisi orang-orang yang bertugas untuk menguraikan atau menjelaskan faktafakta dan biasanya setelah mendengar para pihak dan mengupayakan agar mereka mencapai suatu kesepakatan, membuat usulan-usulan guna penyelesaian persoalan. Namun keputusan tersebut tidak mengikat; Fasilitasi (Facilitation), Dalam perkara yang melibatkan lebih dari dua pihak dibutuhkan adanya pihak ketiga yang berperan sebagai fasilitator. Tugasnya membantu pihak yang berperkara dengan cara mencari jalan keluar secara bersama. Dalam hal ini fasilitator hanyalah memberikan fasilitas agar komunikasi para pihak efektif. Fasilitas yang dimaksud termasuk penghubung, penerjemah, sekretariat bersama atau tempat pertemuan.

Penilai Independen, Penggunaan jasa pihak ketiga yaitu penilai independen yang tidak memihak adalah salah satu proses yang dapat digunakan dalam penyelesaian suatu perkara. Pihak ketiga yang independen dan tidak memihak ini akan memberikan pendapat fakta-fakta dalam perkara. Pihak-pihak yang berperkara menyetujui pendapat penilai independen menjadi suatu keputusan final dan mengikat. Jadi penilai independen ini selain pelaku investigasi juga pembuat keputusan. Pihak-pihak bersengketa juga dapat menjadikan pendapat atau saran dari penilai independen sebagai bahan pertimbangan dalam negosiasi selanjutnya. Arbitrase berasal dari kata arbitrare (bahasa latin) yang berarti kekuasaan untuk menyelesaikan suatu perkara menurut kebijaksanaan.

Arbitrase merupakan proses mudah yang dipilih para pihak secara sukarela karena ingin perkaranya diputus oleh juru pisah yang netral keputusan juru pisah ini bersifat final dan mengikat. Pengertian arbitrase menurut Pasal 1 Ayat (1) UU Nomor 30 Tahun 1999 adalah cara penyelesaian satu perkara perdata di luar pengadilan umum yang didasarkan pada perjanjian arbitrase yang dibuat secara tertulis oleh para pihak yang bersengketa. Rumuskan arbitrase dapat digariskan sebagai suatu penyelesaian perkara oleh seorang atau beberapa arbiter (hakim) yang diangkat berdasarkan persetujuan para pihak dan disepakati bahwa putusan yang diambil nanti bersifat mengikat dan final.

Tahapan-tahapan penyelesaian alternatif sengketa sebagai berikut: Awalnya para pihak yang bersengketa bertemu secara langsung, melakukan konsultasi atau negosiasi dengan itikat baik berdasarkan musyawarah dan mufakat. Penyelesaian sengketa sepenuhnya di tangan mereka. Menentukan sendiri penyelesaian yang mereka inginkan 
berdasarkan kompromi. Dalam waktu 14 hari telah ada suatu kesepakatan tertulis dari mereka. Apabila usaha musyawarah tidak berhasil mereka dapat meminta bantuan pihak ketiga (perseorangan) yang bertindak sebagai mediator. Dalam 14 hari telah tercapai suatu kesepakatan tertulis mereka. Apabila usaha mediasi ini tidak berhasil, maka mereka dapat menghubungi Lembaga Arbitrase atau Lembaga Alternatif Penyelesaian Sengketa untuk meminta seorang mediator.

Hal ini bertujuan untuk mencari jalan keluar. Mediator memegang teguh kerahasiaan. Paling lama dalam 30 hari harus tercapai kesepakatan tertulis yang ditandatangani oleh semua pihak yang terkait. Kesepakatan tertulis dan bersifat final mengikat ini harus dilaksanakan para pihak dengan itikad baik serta wajib didaftarkan di Pengadilan Negeri paling lama 30 hari sejak penandatanganan. Apabila usaha musyawarah dan mediasi juga tidak berhasil, maka para pihak yang bersengketa dapat menyelesaikan sengketanya melalui arbitrase. Ini harus diselesaikan dalam waktu 180 hari sejak arbiter atau majelis arbitrase dibentuk.

\section{SIMPULAN}

Penyelesaian peselisihan kerja sama antara asosiasi bongkar muat dengan koperasi tenaga bongkar muat upaya karya dapat dilakukan dengan cara Litigasi maupun Non Litigasi. Berdasarkan BW, apabila hal yang diperjanjikan oleh para pihak melanggar atau bertentangan hokum maka akibat hukumnya adalah perjanjian tersebut batal demi hukum. Berkaitan dengan syarat keabsahan perjanjian dan teori perjanjian klasik, dalam hukum perjanjian dikenal beberapa asas diantaranya: asas konsensualisme, asas kebebasan berkontrak, asas itikad baik. berpendapat bahwa asas itikad baik, asas kebebasan berkontrak dan konsensualisme, saling berjalin satu dengan yang lain tanpa dapat dielakkan kalau menginginkan lahirnya suatu kontrak yang sehat (fair) demi terbingkainya aktifitas bisnis dalam hidup keseharian.

\section{DAFTAR PUSTAKA}

Abdurrasyid, P. (2002). Abitrase dan Alternatif Penyelesaian Sengketa.Jakarta: Fikahati Aneska.

Badan Pembinaan Hukum Nasional (BPHN), Simposium Hukum Perdata Nasional, Kerjasama Badan Pembinaan Hukum Nasional (BPHN), Fakultas Hukum Universitas Gadjah Mada, Yogyakarta, 21-23 Desember 1981. dalam Agus Yudha Hernoko. 2008. Asas Proporsionalitas Dalam Kontrak Komersial, Yogyakarta: Laksbang Mediatama.

Badrulzaman, M.D. (2006). KUHPerdata Buku III, Bandung: Penerbit Alumni. 
Dharmaputra, R.Y. \& Januari S., (2010), Pelaksanaan Perjanjian Kredit Modal Kerja di Bank Mandiri (PERSERO) Tbk. Cabang Binjai di Tinjau dari Undang-Undang Nomor 8 Tahun 1999 Tentang Perlindungan Konsumen, Mercatoria, 3 (2): 71-87

Emirzon, J. (2000). Alternatif Penyelesaian Sengketa di Luar pengadilan.Jakarta: Gramedia Pustaka Utama. http://www.legalakses.com/asas-asas-perianjian/

Kamaluddin. (1983). Sarana Penunjang Angkutan Laut. Jakarta: Bina Aksara.

Marpaung, B. Arifin, S, \& Hidayani, S (2016). Tinjauan Yuridis Akibat Hukum Terhadap Wanprestasi Dalam Perjanjian Kredit (Studi Putusan Nomor 607/Pdt.G/2013/ Pn.Mdn) Jurnal Ilmiah Penegakan Hukum, 3 (2) 2016: 114- 120

Nasution, R.S. (2018). Analisis Yuridis Perjanjian Usaha Waralaba Berdasarkan Kitab Undang-Undang Hukum Perdata, 5 (2): 94-100.

Projhodikoro, W. (1982). Hukum Perkapalan dan Pengangkutan Laut. Jakarta: Bina Aksara.

Salindheo, J. (1988). Masalah Tanah Dalam Pembangunan, Cetakan Kedua. Jakarta: Sinar Grafika, 1988.

Sembiring, S. (2006). Himpunan Lengkap Peraturan Perundang-Undangan tentang Badan Peradilan dan Penegakan Hukum, Bandung: Nuasa Aulia.

Simorangkir, S.H.E., \& Januari S., (2010), Analisis Terhadap Perjanjian Pemasangan Air Minum Antara PDAM Tirtanadi Sumatera Utara dengan Pelanggan di Cabang Medan Denai, Mercatoria, 3 (2): 133143

Soekanto, S. (1981). Pengantar Penelitian Hukum, Jakarta: UI Press.

Sumardi, F. \& Mubarak, R. (2018). Tinjauan Yuridis Terhadap Perjanjian Kerja Yang Dibuat Secara Lisan, 5 (1) $2018: 8-13$.

Suryabrata, S. (2006). Metodologi Penelitian. Jakarta: Rajawali Pers.

Syaparudin, Ferri A.S., \& Henry D.S., (2010), Perlindungan Hukum bagi Para Pihak dalam Perjanjian Franchise, Mercatoria, 3 (2): 144-162

Wantjik, K. (1997). Hukum Acara Perdata, Jakarta: Ghalia Indonesia. 